\title{
SISTEM PENGENDALIAN PEMESANAN BAHAN BAKU SUSU BUBUK SERTA KEBIJAKANNYA
}

\author{
Deden Jaelani $^{1}$, Darmawan Yudhanegara ${ }^{1^{*}}$ \\ ${ }^{1}$ Program Studi Teknik Industri, Sekolah Tinggi Teknologi Wastukancana \\ Jln. Cikopak No.53, Purwakarta, Jawa Barat \\ *Penulis Korespondensi : darmawan@stt-wastukancana.ac.id
}

\begin{abstract}
Formula milk production companies are faced with an optimal ordering control system. The availability of raw materials is a measure of the performance of the ordering system at a low cost. This research was conducted to determine the optimal order point with a minimum ordering cost. Ordering decision making is considered from company policy because of the budget. The results of this study indicate that the frequency of purchasing raw materials is 9 times the purchase of raw materials in one year period, 12 times a year of policy. The total purchase of raw material inventories was $R p$. 48,671,774, and the policy was $R p$. 50,765,157.35 per year. The savings in ordering costs amounted to Rp. 2,093,383.35. The reorder point is 5,634 pcs.
\end{abstract}

Keywords: Controlling, Cost, Optimal

\section{Pendahuluan}

Karawang salah satu kota di Jawa Barat, saat ini menjadi kota kawasan industri terbesar di Indonesia sesuai dengan julukannya sebagai kota kawasan industri karawang, kota ini hadir dengan perusahaan-perusahaan yang berdiri di atas lahan penduduk pada tataran sunda dengan lahan dengan luas kurang lebih 3.123 hektar. PT. KMI adalah sebuah perusahaan yang bergerak di bidang industri olahan pertanian dan peternakan, salah satunya produksi pembuatan susu bubuk, yang berlokasi di kawasan industri Indotaisei kota bukit indah Cikampek-Karawang. Perusahaan bergerak memproduksi susu beberapa merek yang sudah tersebar di seluruh Indonesia sudah cukup lama.

Dalam pengolahannya, perusahaan ini menggunakan bahan baku susu bubuk untuk produksinya sebagai bahan utama dalam proses produksi, sehingga pengendalian sistem pemesanan menjadi prioritas. Dengan adanya faktor bahan baku lebih banyak berasal dari luan negeri, dengan cara mengimpor menjadi bahan pertimbangan dalam sistem pengendalian, sedangkan secara kualitas lebih menjamin (Costantino et al. 2015). Perusahan belum mampu memproduksi bahan baku yang diambil dari barang dometik, karena berkaitan dengan kualitas dan jalinan kerjasama dengan pemasok bahan baku yang cukup lama. Pada permasalahannya, saat ini bahan baku yang ada dalam pengendalian perusahaan yaitu adanya pemesanan yang sangat berlebihan yang mengakibat barang dalam gudang menumpuk dan kadaluarsa dan tidak standar untuk masuk ke produksi. Permasalah kedua adalah maslah biaya anggaran. Biaya yang disediakan dalam pembelian bahan baku menjadi kebijakan dalam pemesanan dari pusat, sehingga perlu dilakukan penghematan terhadap jumlah pemesanan dan frekuensi pemesanan bahan baku dari pemasok, dasar pemesanan dengan kebijakan pernah dilakukan dalam penelitian sebelumnya (Hu, Lim, and Lu 2013). 
Adanya penumpukan persediaan bahan baku bisa saja didapat dari bahan baku karena bahan baku ini yang bernilai tinggi, akibatnya dihindari adanya penumpukan persediaan dari total biaya produksi terhadap harga pokok produksi cukup dominan secara keseluruhan. Penyebab resiko penumpukan persediaan bisa terjadi karena terlalu lama barang disimpan digudang sehingga membuat kualitas hasil produksi susu bubuk berkurang (Taleizadeh et al. 2016).

Sistem pemesanan yang dilakukan bahan baku pada bahan baku susu formula dengan bahan baku yang lain adalah waktu masa bahan baku segera angkat ke produksi serta lamanya bahan baku yang dari pemasok memiliki kadaluarsa, sehingga perhitungan waktu antara waktu setelah produksi di pemasok dengan waktu penyimpanan dan proses pengiriman kemudian diterima ke perusahaan (inbound) menjadi pertimbangan yang cukup ketat, namun hal tersebut tidak bisa dilakukan sesuai harapan, maka diperlukan pengendalian pemesanan dengan sistem pengendalian pemesanan khusus susu bubuk.

Sisi lain dari waktu pemesanan (inbound) menjadi perioritas, perusahaan memberikan kebijakan posisi sistem pemesanan dengan pengendalian sistem secara keseluruhan. Artinya jika ditinjau dari sistem keseluruhan bahwa sistem pengendalian pemesanan merupakan subsistem dari perusahaan. Karena aspek yang menjadi objek dalam penelitian ini adalah sistem pengendalian pemesanan, peranan dalam kebijakan diposisikan sebagai pertimbangan dalam sistem pengendalian.

Dari permasalahan tersebut diperlukan dua faktor yang harus kita perhatikan yaitu yang terdiri dari faktor biaya dan resiko. Faktor pertama, biasanya biaya didapat dari biaya jaminan barang, biaya asuransi atau biaya tenaga karyawan, sedangkan faktor kedua yaitu adanya resiko bahan baku yang rusak karena adanya lama penyimpanan, sedangkan persediaan selalu tersedia. Kemudian ditambahkan dengan pertimbangan kebijakan didalamnya dalam pengambilan keputusan pengendalian sistem pemesanan. Sedangkan hubungan dengan bahan baku yang dipesan ditinjau dari waktu inbound dari pemasok dengan bahan baku yang diterima oleh perusahaan.

Manfaat penelitian ini diharapkan dapat mencapai tujuan meminimasi biaya pemesanan dengan mengelaborasikan kebijakan perusahaan. Hasil dari penelitian ini diharapkan memperoleh keputusan untuk pengendalian dari waktu yang diperlukan pemesanan, frekuensi yang optimal, serta kondisi pada bahan baku apabila dipelukan pada sisi produksi, keadaan pemasok, waktu inboud pemesanan selama satu tahun kedepannya pada tahun ini.

Perusahaan memiliki visi saat ini yaitu menjadi perusahaan toll manufacturing berkelas dunia .Dengan demikian, perusahaan bertekad untuk menghasilkan produk-produk berkelas tinggi dan aman sesuai dengan persyaratan pelanggan, standar nasional dan internasional serta perundangundangan yang berlaku.

\section{Metodologi}

Secara metodologi penelitian yang dilakukan pada sistem pengendalian bahan baku susu dengan bahan baku lainnya, terletak pada prinsipnya sama dengan sistem pengendalian terhadap produk yang lain, namun berbeda dalam penelitian disini adalah mempertimbangkan kebijakan perusahaan dalam sistem pengendalian pemesanan bahan baku secara laingsung, yang saat ini perusahaan lakukan.

Pendekatan penelitian yang digunakan adalah pendekatan kualitatif dan kuantitif. Dengan melakukan analisis perbandingan terhadap nilai yang diperoleh dari data-data dan proyeksi yang ada dilapangan (Irmayanti 2019). 
Perhitungan dilakukan secara manual terhadap parameter-parameter sistem. Sedangkan secara umum penelitian dilakukan dengan pendekatan penelitian pada umumnya. Seperti yang digambarkan dibawah ini

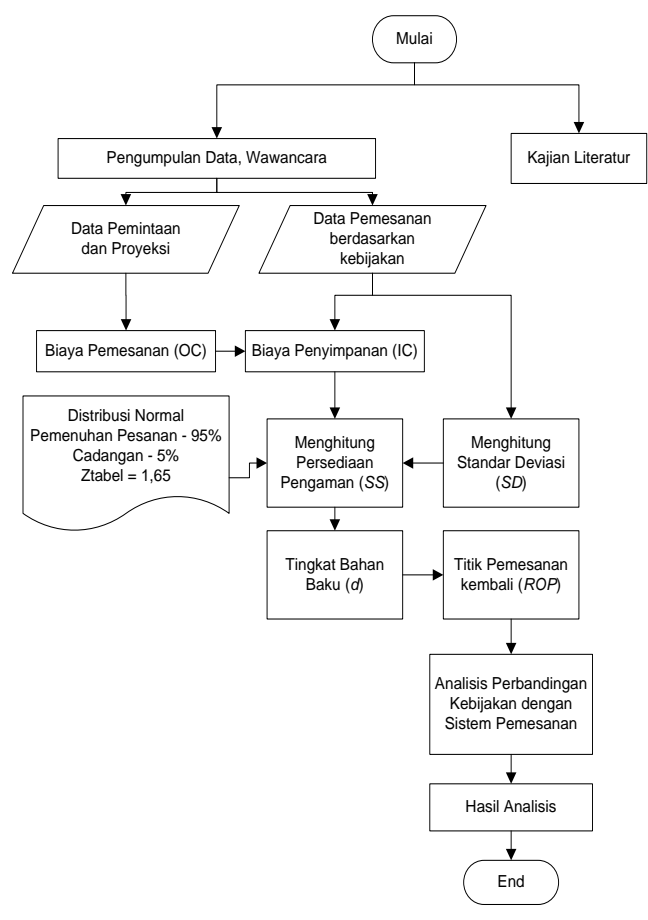

Gambar 1. Metodologi Pemecahan

Model yang digunakan dititikberatkan pada data-data eksisting dan proyeksinya. Sedangkan untuk kebijakan terhadap anggaran perusahaan serta adanya perubahan strategi dari hulu perusahaan (Indah and Maulida 2018; Daud 2017). Metodologi dalam pemecahan untuk merancang sistem pengendalian ini dilakukan secara kombinasi antara perhitungan secara objektifitas dan pertimbangan dengan kebijakan yang sedang berjalan.

Kedua hal tersebut menjadi dua faktor yang besar. Secara metodologi digunakan dengan menggunakan elaborasi antara keduanya. Elaborasi merupakan pendekatan yang berguna dalam melakukan dua hal yang berbeda yang bertolak belakang yang tujuannya untuk memperoleh titik temu optimal diantara keduanya.

\section{Metode yang digunakan}

Secara pengetiannya bahwa titik pemesanan ekonomis (economic order quantity) yang merupakan suatu model guna menemukan titik optimal dengan cara perhitungan persediaan barang untuk manajemen persediaan supaya perusahaan dapat terhindar dari penumpukan barang tersimpan di gudang, seperti adanya penumpukan stok barang bisa saja didapat dari bahan baku atau barang yang bernilai lumayan, apalagi seperti bahan baku susu, akibatnya penumpukan persediaan dari total biaya produksi atau harga pokok produksi yang dapat diperoleh sangat tinggi secara keseluruhan.

Model ini dikembangkan pada tahun 1913 oleh Ford Whitman Haris. Merupakan insinyur produksi dengan konsep persediaan square-root formula. Bekerja di perusahaan manufaktur listrik westinghouse.

\section{Produk}

Susu bubuk adalah susu cair hewani yang dipanaskan sedemikian rupa menggunakan alat pengering hingga kering, sehingga menghasilkan bentuk menjadi bubuk. Jenis susu ini memiliki daya tahan yang paling lama jika dibandingkan dengan jenis susu lainnya, sehingga tidak perlu disimpan di lemari pendingin karena memiliki kandungan uap air yang sangat rendah. Produk susu ini menjadi pertimbangan dalam memperpanjang produk ini terkontaminasi lamanya penyimpanan

Susu bubuk yang beredar di pasaran umumnya berupa susu skim, full cream, ataupun whole milk. Kandungan gizi pada susu bubuk umumnya difortifikasi, sehingga tidak alami. Tetapi bukan berarti tidak sehat, namun dapat memilih susu bubuk dari produsen tepercaya dengan tetap mencermati komposisi bahan-bahan tambahan yang aman dan 
sehat. Perusahaan mengutamakan kepada kesehatan masyarakat.

\section{Pengumpulan dan Pengolahan Data}

Pengumpulan data dilakukan secara survey dan hasil wawancara dengan pihak yang terkait dengan data tersebut. Data-data serta olahannya diuraikan berdasarkan parameter-parameter pada model kuantititas pemesanan ekonomis dasar, yang disesuaikan dengan objek bahan baku yang dilakukan.

Data primer yang dilibatkan dalam penelitian ini diambil secara langsung, hanya pada angka-angka yang masa mendatang dilakukan dengan metode peramalan. Penelitian diambil data yang dipergunakan selama satu tahun, guna pengambilan keputusan untuk pengendalian pemesanan sampai 31 Desember 2021 dengan evaluasi setiap bulannya.

\section{Data Permintaan dan Proyeksinya}

Persediaan bahan baku bahan baku susu dapat mempertimbangkan dari jumlah permintaan selama satu tahun per bulannya berdasarkan data masa lalu (Juli 2020 - Maret 2021) dan proyeksi dengan metode modifikasi rata-rata bergerak pada bulan April 2021 - Juli 2021, karena disesuaikan dengan masa pandemi covid-19.

Tabel 1. Data dan Proyek Pemintaan

\begin{tabular}{clc}
\hline No & \multicolumn{1}{c}{ Bulan } & $\begin{array}{c}\text { Permintaan } \\
\text { (box) }\end{array}$ \\
\hline 1 & Juli & 21,179 \\
2 & Agustus & 19,556 \\
3 & September & 21,851 \\
4 & Oktober & 22,228 \\
5 & November & 23,953 \\
6 & Desember & 20,968 \\
7 & Januari & 19,973 \\
8 & Februari & 17,407 \\
9 & Maret & 19,943 \\
10 & April & 20,874 \\
11 & Mei & 17,983 \\
12 & Juni & 21,865 \\
\hline & $\sum x_{o}$ & 247,907 \\
\hline
\end{tabular}

Kepala produksi Bertugas untuk menjalankan dan mengawasi seluruh kegiatan yang berkaitan dengan arus produksi, dari material hingga produk jadi. Sedangkan karyawan pengadaan bertugas membeli bahan baku produksi. Selain itu divisi ini juga bertugas menjalin kerjasama dengan pihak supplier bahan baku guna menjamin kelangsungan proses produksi perusahaan, salah satunya dengan pengendalian pemesanan.

Susunan data permintaan selama satu tahun dihitung semuanya kedalam bentuk total permintaan $\left(x_{o}\right)$. Hal ini dikaitkan di dalam permintaan untuk persediaan yang akan digunakan dalam produksi. Sistem pengendalian produksi akan menerima data penerimaan dari departemen pemasaran untuk digunakan dalam persiapan penentuan produksi.

Departemen produksi koordinasi bagian gudang dan departemen pengadaan, kaitan dalam penelitian ini adalah pengadaan bahan baku pada bahan baku susu, titik optimal yang dilakukan dari jumlah yang diminta dari pemasaran, keadaan jumlah yang ada digudang, dengan jumlah yang semestinya dilakukan pemesanan kembali.

Sistem pemesanan bahan baku menerima data dari produksi sejumlah bahan baku yang harus tersedia di gudang, namun sistem pemesanan tidak secara langsung mengambil keputusan yang diterima data dari produksi, salah satu pertimbangan dalam pemesanan adalah kebijakan setiap periode tertentu yang berbeda-beda, berkaitan dengan anggaran. Sedangkan dari departemen pengadaan akan melihat ketersediaan bahan baku dari pemesok dan perhitungan lamanya dalam proses pemesanan sampai barang itu diterima oleh perusahaan.

Sedangkan frekruensi $(f)$ yang dilakukan dalam satu tahun. Salah satu 
kebijakan jumlah pemesanan dalam satu tahun. Kebijakan dari pusat menyerahkan secara langsung kepada departemen pengadaan, sedangkan departemen pengadaan memberikan rekomendasi ke bagian keuangan pusat. Sistem pengadaan melakukan internal terhadap kondisi pemasok dalam ketersediaan dan masa kadaluarsa dari bahan baku yang dipesan. Kebutuhan bahan baku susu bubuk dapat dilihat pada diagram blok seperti pada gambar 2 selama satu tahun.

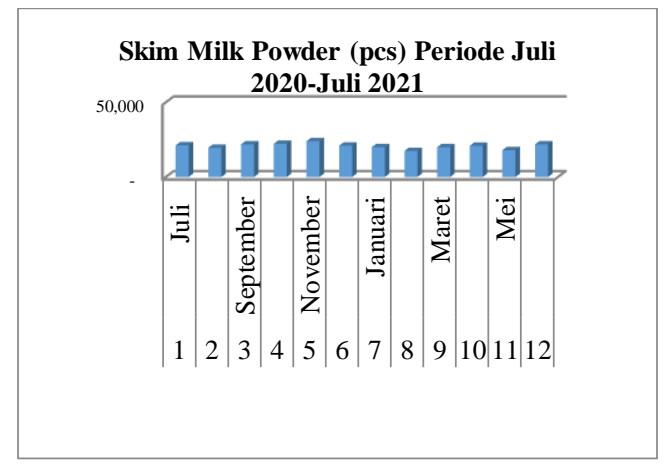

Gambar 2. Kebutuhan bahan baku

Dengan tersedianya persediaan maka diharapkan perusahaan dapat melakukan proses produksi sesuai kebutuhan atau permintaan konsumen sehingga terjadi adanya biaya pemesanan $(O C)$. Selain itu dengan adanya persediaan yang cukup di gudang juga diharapkan dapat memperlancar kegiatan produksi atau pelayanan kepada konsumen. Perusahaan dapat menghindari terjadinya kekurangan barang, keterlambatan jadwal pemenuhan produk yang dipesan konsumen dapat merugikan perusahaan dalam hal ini image yang kurang baik, sehingga diperlukan biaya simpanan (IC). secara metodologi, hal ini sama dengan perhitungan dengan menggunakan parameter, pada bahan baku susu bubuk, adanya biaya akibat dari waktu yang dikeluarkan pada saat waktu pemesanan inbound.

Biaya persediaan dan pemesanan bahan baku dikeluarkan oleh perusahaan guna jika ditinjau dari bahan baku susu buku dapat diketahui dari proses kedatangan dari pemasok sampai pada bahan baku masuk ke produksi. Untuk mendapatkan persediaan bahan baku yang dibutuhkan diperlukan setiap hal yang dapat menyebabkan biaya itu terjadi. Biaya persediaan harus dipersiapkan dan direncanakan secara maksimal oleh pengelola guna menghindari adanya biaya yang terbuang sia-sia, seperti yang terjadi pada susu bubuk ini.

Sebagian besar dari sumber-sumber perusahaan juga sering dikaitkan didalam persediaan yang akan digunakan dalam perusahaan, secara semua nilai dari persediaan harus dicatat, digolonggolongkan menurut jenisnya yang kemudian dibuat perincian dari masingmasing barangnya dalam suatu periode yang bersangkutan. Namun hal ini tidak bisa dilakukan secara terus menerus, namun untuk susu bubuk ini perlu adanya penilaian terhadap jangka waktu dari pemasok ke barang itu masuk ke produksi.

Pada akhir suatu periode, pengalokasian biaya-biaya dapat dibebankan pada aktivitas yang terjadi dalam periode tersebut dan untuk aktivitas mendatang juga harus ditentukan atau dibuat dengan melakukan proyeksi, seperti pada penelitian ini. Dalam mengalokasikan biaya-biaya, biasanya setiap perusahaan mengenal pusat-pusat biaya untuk mengukur hasil yang telah dicapai dalam suatu periode tertentu sehubungan dengan penentuan dari posisi keuangan perusahaan sebagai suatu unit usaha.

Kegagalan dalam mengalokasikan biaya akan menimbulkan kegagalan dalam mengetahui posisi keuangan dan kemajuan yang telah dicapai oleh suatu perusahaan (Irmayanti 2019), sedangkan dalam susu bubuk ini tergantung bagaimana mengendalikan waktu terhadap jangka waktu dari pemasok dan masuk ke produksi. Tentu ini dilakukan asumsi terhadap penjagaan kualitas dari susu yang memiliki sifat yang sama.

Biaya pemesanan adalah biaya yang dikeluarkan sehubungan dengan kegiatan 
pemesanan bahan baku, sejak dari penempatan pemesanan sampai tersedianya barang digudang. Biaya pemesanan ini meliputi semua biaya yang dikeluarkan dalam rangka mengadakan pemesanan barang, yang dapat mencakup biaya administrasi dan penempatan pesanan, biaya pemilihan pemasok, biaya pengangkutan dan bongkar muat, biaya penerimaan dan pemeriksaan barang. Biaya pemesanan dinyatakan dalam rupiah per pesanan, tetapi tergantung dari berapa kali pesanan dilakukan.

Tabel 2. Biaya Pemesanan

\begin{tabular}{clc}
\hline No & \multicolumn{1}{c}{ Bulan } & $\begin{array}{c}\text { Permintaan } \\
\text { (box) }\end{array}$ \\
\hline 1 & Juli & $2,830,000$ \\
2 & Agustus & $2,600,000$ \\
3 & September & $2,825,000$ \\
4 & Oktober & $2,840,000$ \\
5 & November & $2,835,000$ \\
6 & Desember & $2,600,000$ \\
7 & Januari & $2,850,000$ \\
8 & Februari & $2,590,000$ \\
9 & Maret & $2,595,000$ \\
10 & April & $2,830,000$ \\
11 & Mei & $2,600,000$ \\
12 & Juni & $2,600,000$ \\
\hline \multicolumn{2}{c}{ Total Biaya $\left(O_{C}\right)$} & $32,595,000$ \\
\hline
\end{tabular}

Biaya pemesanan biaya tetap yang harus dikeluarkan perusahaan setiap kali melakukan pemesanan untuk mendapatkan bahan baku atau barang dari luar. Biaya pemesanan untuk bahan baku skim milk powder mencakup biaya telepon/internet dan biaya bongkar. Biaya telepon/internet dan biaya bongkar selama periode setahun dapat dilihat pada tabel.

Apabila perusahaan memproduksi persediaan sendiri, tidak membeli dari pemasok, biaya ini disebut sebagai biaya set-up, yaitu biaya yang diperlukan untuk menyiapkan peralatan, mesin atau proses manufaktur lain dari suatu rencana produksi. Analog biaya dengan biaya pemesanan, biaya set-up dinyatakan dalam rupiah per production run, tidak tergantung dari jumlah yang diproduksi. Biaya simpanan Perhitungannya sebesar

$$
\begin{gathered}
O C=\frac{\sum x_{o}}{f} \\
O C=\frac{32,595,000}{12} \\
O C=2,716,250
\end{gathered}
$$

Yaitu $O C$ : total biaya pemesanan kembali, $x_{o}$ : total kebutuhan bahan baku satu tahun $f$ : frekuensi dalam setiap kali pemesanan.

\section{Biaya Simpanan}

Biaya penyimpanan adalah biaya yang harus dikeluarkan karena perusahaan menyimpan bahan baku digudang. Biaya untuk bahan baku terdiri dari biaya material handling dan biaya fasilitas penyimpanan. Besarnya biaya simpan bahan baku ditetapkan oleh perusahaan sebesar $10 \%$ dari nilai persediaan.

Tabel 3. Biaya Simpanan

\begin{tabular}{clr}
\hline No & \multicolumn{1}{c}{ Bulan } & $\begin{array}{c}\text { Simpanan } \\
\text { (box) }\end{array}$ \\
\hline 1 & Juli & $22,825,500$ \\
2 & Agustus & $4,132,500$ \\
3 & September & $4,860,000$ \\
4 & Oktober & $4,207,500$ \\
5 & November & $42,540,000$ \\
6 & Desember & $54,067,500$ \\
7 & Januari & $50,985,000$ \\
8 & Februari & $65,115,000$ \\
9 & Maret & $58,807,500$ \\
10 & April & $61,972,500$ \\
11 & Mei & $40,117,500$ \\
12 & Juni & $26,340,000$ \\
\hline \multicolumn{2}{c}{ Total Biaya $\left(s_{c}\right)$} & $436,267,500$ \\
\hline
\end{tabular}

Jika dihitung biaya simpanan diperoleh sebesar 


$$
\begin{gathered}
I C=\frac{\sum s c}{x_{o}} \\
I C=\frac{436,267,500}{247,907} \\
I C=1,759,8
\end{gathered}
$$

Persediaan adalah sebagai suatu aktiva yang meliputi barang-barang milik perusahaan dengan maksud untuk dijual dalam suatu periode usaha yang normal, atau persediaan barang-barang masih dalam pengerjaan atau proses produksi, ataupun persediaan barang baku yang menunggu penggunaannya dalam suatu proses produksi. Biaya dalam menunggu tidak dilakukan dalam penelitian ini

\section{Kebijakan Internal}

pemesanan dalam setahun sebanyak $12 \mathrm{kali}$, perusahaan ini tidak memproduksi bahan baku susu sendiri. Namun mengimpor bahan baku susu dari Australia yang selama ini menjadi rekan kerjanya. Pembelian bahan baku $(P P)$ dapat diperhitungkan berdasarkan kebijakan perusahaan yang melakukan pemesanan setiap bulan sekali sebesar

$$
\begin{gathered}
P P=\frac{x_{o}}{f} \\
P P=\frac{247,907}{12} \\
P P=20,658.91
\end{gathered}
$$

Sedangkan untuk total biaya persediaan (TIC) yang berfungsi agar dapat menghitung biaya persediaan yang diperlukan oleh perusahaan sebesar

$$
T I C=\left[\frac{D}{Q} S\right]+\left[\frac{Q}{2} H\right]
$$

$$
\begin{aligned}
& \text { TIC }=\left[\frac{247.907}{20.658} R p 2.716 .250\right] \\
& {\left[\frac{20.658}{2} R p 1.759\right]} \\
& T I C=R p 32.596 .446,35 \\
& +R p 18168711
\end{aligned}
$$

$$
T I C=50,765,157.35
$$

Jadi ini merupakan total biaya persediaan yang harus ditanggung.

\section{Menghitung Pemesanan Ekonomis}

Konsep dasar jumlah pemesanan ekonomi (EOQ) adalah meminimalkan biaya total untuk penyimpanan persediaan dan memproses pesanan. Kebijakan perusahaan untuk memesan bahan baku dalam jumlah besar membuat biaya simpan bahan baku menjadi besar walaupun frekuensi pemesanan sangat sedikit dalam satu tahun.

$E O Q=\sqrt{\frac{2 D S}{H}}$

$$
E O Q=\sqrt{\frac{2 \times 247.907 \times \mathrm{Rp} .2 .716 .250}{1.759}}
$$

$E O Q=27,670.14$

Frekuensi Pemesanan Bahan Baku, dengan menggunakan model jumlah pemesanan ekonomis jumlah frekuensi pemesanan dalam satu tahun atau sering disebut frekuensi pembeliaan dapat dihitung

$$
\begin{aligned}
& f=\frac{D}{Q} \\
& f=\frac{247.907}{27.670}
\end{aligned}
$$




$$
f=8.95
$$

Jadi frekuensi pemesanan bahan baku menurut metode EOQ adalah 9 kali dalam setahun.

Total Biaya Persediaan untuk kebijakan internal agar dapat menghitung biaya persediaan maka terlebih dahulu diketahui

$$
\begin{aligned}
\text { TICP } & =\left[\frac{D}{Q} S\right]+\left[\frac{Q}{2} H\right] \\
\text { TICP }= & {\left[\frac{247.907}{27.670} R p 2.716 .250\right] } \\
& +\left[\frac{27.670}{2} R p 1.759\right] \\
\text { TICP } & =24,336,009+24,335,765 \\
\text { TICP } & =R p 48.671 .774 .
\end{aligned}
$$

\section{Analisis dan Pembahasan}

Analisis dilakukan berdasarkan variabel yang digunakan untuk mendukung dalam memperoleh hasil analisis. Analisis perbandingan membantu dalam menentukan pengendalian yang dilakukan analisis terhadap objek sistem pemesanan bahan baku susu bubuk, sedangkan kebijakan membantu dalam menjaga anggaran yang dibatasi oleh perusahaan terhadap batasan-batasan keuntungan secara keseluruhan dari aspek diluar dari sistem pemesanan.

\section{Persediaan Pengaman}

Persediaan pengaman ini sering sering juga dengan istilah safety stock $(S S)$. Fungsi persediaan pengaman sangat diperlukan guna menunjang kelancaran proses produksi yang berlangsung, seperti halnya menghindari kekurangan bahan baku yang akan mengakibatkan proses terhenti dan karyawan tidak bekerja. Hal ini sangat merugikan bagi pihak perusahaanya. Dalam memperhitungkan persediaan pengaman berdistribusi normal, dengan mambandingkan rata-rata bahan baku dengan pemakaian bahan baku yang sesungguhnya kemudian dicari penyimpangannya $(S D)$ dari permintaan $\left(x_{d}\right)$ dan kebijakan pemesanan bahan baku $\left(x_{o}\right)$ secara merata per bulannya selama setahun diperoleh sebesar

$$
\begin{aligned}
& S D=\sqrt{\frac{\sum\left(x_{d}-x_{o}\right)^{2}}{n}} \\
& S D=\sqrt{\frac{50,358,832}{12}} \\
& S D=2048,55
\end{aligned}
$$

Sedangkan persediaan pengaman diperoleh sebesar

$$
\begin{gathered}
S S=Z_{\text {tabel }} \times S D=1,65 \times 2048,55 \\
S S=3380,1
\end{gathered}
$$

Sebelum menghitung titik pemesanan maka terlebih dahulu dicari tingkat penggunaan bahan baku per hari $(d)$ yaitu sebesar

$$
\begin{gathered}
d=\frac{D}{t} \\
d=\frac{247,907}{220} \\
d=1126,7
\end{gathered}
$$

\section{Titik Pemesanan Kembali}

Titik pemesanan kembali $(R O P)$ memiliki waktu tunggu $(L)$ dalam menunggu pemesanan bahan baku susu bubuk selama 5 hari, sedangkan rata-rata jumlah kerja karyawan selama 220 hari dalam setahun, sehingga diperoleh

$$
\begin{aligned}
& R O P=d \times L \\
& R O P=1126,7 \times 5 \\
& R O P=634,25
\end{aligned}
$$




\begin{abstract}
Perbandingan Kebijakan Perusahaan dengan perhitungan pemesanan ekonomis memperoleh langkah untuk pengambilan keputusan. Dari hasil yang telah dianalisis di atas maka telah diketahui perbandingan antara total biaya yang dikeluarkan bila menggunakan kebijakan perusahaan dan kebijakan dengan menggunakan model.
\end{abstract}

Tabel 4. Analisis Perbandingan

\begin{tabular}{lrr}
\hline \multicolumn{1}{c}{ Deskripsi } & \multicolumn{1}{c}{ Kebijakan } & \multicolumn{1}{c}{ Model } \\
\hline $\begin{array}{l}\text { Pemberian } \\
\text { rata-rata } \\
\text { bahan baku }\end{array}$ & 20,658 & 27,670 \\
$\begin{array}{l}\text { Total biaya } \\
\text { persediaan }\end{array}$ & $50,765,157$ & $48,671,774$ \\
$\begin{array}{l}\text { Frekuensi } \\
\text { Pemesanan }\end{array}$ & 12 & 9 \\
$\begin{array}{l}\text { Persediaan } \\
\text { pengaman }\end{array}$ & 0 & 3,380 \\
$\begin{array}{l}\text { Titik } \\
\text { pemesanan } \\
\text { kembali }\end{array}$ & 0 & 5,634 \\
\hline
\end{tabular}

Dari tabel diatas dapat dilihat bahwa biaya yang dikeluarkan perusahaan sebesar Rp. 50.765.157, sedangkan total biaya persediaan yang dikeluarkan perusahaan sebesar Rp. 48.671.774, dapat diketahui penghematannya sebesar Rp 2.093.383. Oleh sebab itu, penggunaan metode EOQ pada KMI merupakan biaya peluang bagi perusahaan karena dengan menjalankan kebijakan persediaan bahan baku yang dijalankan perusahaan selama ini, perusahaan mengorbankan penghematan biaya bila tidak menggunakan metode EOQ.

\section{Kesimpulan}

Dari serangkaian penelitian yang dilakukan maka dapat membuahkan hasil yaitu menggambarkan pencapaian tujuan penelitian atau temuan ilmiah yang diperoleh, yaitu
1. Pemesanan dapat dilakukan dengan menemukan optimalisasi pemesanan yang hemat, namun pertimbangan kebijakan internal tetap dipertimbangkan secara elaboratif.

2. Model yang digunakan untuk menentukan jumlah pemesanan yang ekonomis hanya ditinjau dari jumlah saja, namun tidak cukup untuk pertimbangan adanya pemesanan barang yang memiki kadaluarsa pada bahan baku susu bubuk, sehingga diperlukan sistem pengendalian waktu inboud faktor eksternal.

3. Penelitian ini memberikan manfaat pada pengembangan terhadap penilaian optimal yang diperoleh dari kebijakan, tidak semata pada pemesanan bahan baku secara objektif.

4. Kontribusi ilmu pengetahuan yang ada perlu dikembangkan kepada sistem pengendalian pemesanan berdasarkan kadaluarsa bahan baku susu forumula.

5. Hasil diperoleh dari penelitian memberikan porsi terhadap peluang untuk setiap pilihan parameter dalam pengambilan keputusan, penelitian ini menunjukan bahwa elaborasi $50 \%-50 \%$.

\section{Daftar Pustaka}

Costantino, Francesco, Giulio Di Gravio, Ahmed Shaban, and Massimo Tronci. 2015. "The Impact of Information Sharing on Ordering Policies to Improve Supply Chain Performances." Computers and Industrial Engineering 82. https://doi.org/10.1016/j.cie.2015.0 1.024 .

Daud, Muhammad Nur. 2017. "Analisis Pengendalian Persediaan Bahan Baku Produksi Roti Wilton Kualasimpang." Jurnal Samudra Ekonomi Dan Bisnis 8 (2). 
https://doi.org/10.33059/jseb.v8i2. 434.

$\mathrm{Hu}$, Fei, Cheng Chew Lim, and Zudi Lu. 2013. "Coordination of Supply Chains with a Flexible Ordering Policy under Yield and Demand Uncertainty." International Journal of Production Economics 146 (2).

https://doi.org/10.1016/j.ijpe.2013. 08.024.

Indah, Dewi rosa, and Zenitha Maulida. 2018. "Pengendalian Persediaan Bahan Baku Pada PT. Aceh Rubber Industries Kabupaten Aceh Tamiang." Jurnal Manajemen Dan Keuangan 7 (2). https://doi.org/10.33059/jmk.v7i2. 814.

Irmayanti, H. 2019. "Analysis of Raw
Material Ordering with Economic Order Quantity Method." In IOP Conference Series: Materials Science and Engineering. Vol. 662. https://doi.org/10.1088/1757899X/662/3/032011.

Taleizadeh, Ata Allah, Mohsen Lashgari, Roshanak Akram, and Jafar Heydari. 2016. “Imperfect Economic Production Quantity Model with Upstream Trade Credit Periods Linked to Raw Material Order Quantity and Downstream Trade Credit Periods." Applied Mathematical Modelling 40 (1920). https://doi.org/10.1016/j.apm.2016. 05.008 . 